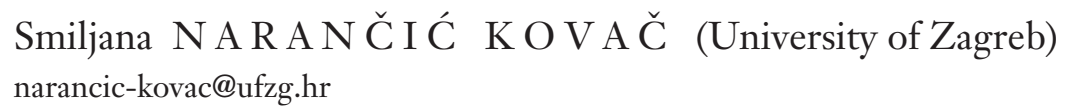

\title{
THE STATUS OF ILLUSTRATIONS IN
} CROATIAN TRANSLATIONS OF CHILDREN'S CLASSICS $^{1}$

Accepted: 25 July 2019

UDK $821.111=163.42$

82-93:81’255.4:75.056

The paper presents a study of the visual discourses of Croatian editions of children's classics translated from English into Croatian. It focuses on trends in using the original illustrations from the source texts or providing new illustrations in individual publications of target texts and on finding and interpreting semantic shifts in images provided by Croatian artists, in comparison with the illustrations in the first editions of the source texts. Interlingual translators adopt various strategies to cope with cultural and stylistic aspects of the source texts, and semantic shifts are almost inevitable. They are even more often perceived in translations of children's literature. Children's books regularly include intersemiotic translations of the verbal text in the form of images, which carry important narrative and cultural meanings. These may become fragile in translation. The analysis of images in Croatian publications with new sets of illustrations has detected modifications of original narrative meanings, leading to semantic shifts. Further, the analysis of the publishing practices has revealed a tendency in the recent period towards introducing new sets of illustrations more often than prior to the 1990s. Finally, the paper considers the reasons for and implications of these findings.

Keywords: children's literature translation, children's classics, interlingual translation, intersemiotic translation, publishing trends

Children's literature depends on images more than any other kind of verbal art. Illustrations can be considered a specific feature of children's literature, due not only to their presence in children's books, but also to their semantic function, which most often leads to modifications of meanings in comparison to those offered by words in isolation. As Zohar Shavit explains, illustrations

${ }^{1}$ This work has been fully supported by the Croatian Science Foundation under the project BIBRICH (UIP-2014-09-9823). 
are an "indispensable feature of children's books" (1986: 167), and this practice has led to the development of the picturebook (167).

Children's literature scholars generally agree that the function of images in picturebooks differs from that in illustrated books. In picturebooks, words and pictures are combined, "mutually and inseparably complementing each other" (Kümmerling-Meibauer 2010: 208). ${ }^{2}$ Martin Salisbury and Morag Styles express this difference even more clearly:

In most contexts, illustration provides a visual accompaniment to words, a prompt or aid to the imagination that aims to augment the overall experience of a book. But in the case of picturebooks, words and pictures combine to deliver the overall meaning of the book; neither of them necessarily makes much sense on its own but they work in unison. (2012: 89)

An illustrated book embraces "one or several pictures" and "the text is not dependent on illustrations to convey its essential message" (Nikolajeva and Scott 2001: 8). However, David Lewis cautions that things are not that simple: "The distinction between these two kinds of text - picturebook and illustrated book - is far from straightforward as it is [...] impossible to 212 ignore the influence of pictures on words, even when illustrations are few and far between" (2001: 68).

If well-made and meaningful, illustrations in illustrated books contribute to narrative meanings and become inseparable components of the whole. The most obvious aspect is the creation of the protagonist's visual identity. For example, Astrid Lindgren's Pippi Longstocking by Ingrid Vang Nyman set the model for all other Pippis that followed. E. W. Kemble's depiction of Mark Twain's Huck Finn is unforgettable, and even in literature aimed at adult readership, a single glance to Josef Lada's illustration of Good Soldier Švejk immediately calls to mind Jaroslav Hašek's satirical narratives. Joyce Irene Whalley claims that in a good illustrated book "pictures enhance or add depth to the text," and in a mere book with pictures, they "lack relevance to the text, or are ill-placed and poorly drawn or reproduced" (2004:318). Such intermedial relations, specific links between words and images, become additionally exposed in translation, because the combinations of verbal and visual meanings become more complex.

${ }^{2}$ More precisely, the picturebook is a multimodal form of art or a combined medium; its visual and verbal discourses relate the story or convey other kinds of information in parallel and in cooperation, and the reader is invited to reconstruct the meanings and combine them into a whole during the process of reading (see Narančić Kovač 2015a). 
This paper focuses on the status of illustrations and their transformations in children's classics in published translations from English into Croatian. The aim is two-fold: (1) to reveal possible trends in publishing practices regarding the preservation of original illustrations from the source text or providing new illustrations in individual target publications, and (2) to consider the implications of new images for possible semantic shifts of narrative and literary meanings of the source texts detected in publications of translated children's classics. Three titles are used for the analyses: Carroll's Alice's Adventures in Wonderland, originally illustrated by John Tenniel (1865), Kipling's fust So Stories, illustrated by himself (1902), and Milne's collection of stories Winnie-the-Pooh, illustrated by E. H. Shepard (1924). They have been selected because several Croatian editions of those titles exist and because of specific semantic relationships established between words and illustrations in each of them.

\section{THEORETICAL BACKGROUND}

The semantic relationships between images and words, and between source and target texts are considered as different modes of translational relationships, based on Roman Jakobson's widely known division of ways of interpreting a verbal sign. The concepts of interlingual translation and intersemiotic translation are directly relevant for the present research. Interlingual translation is "an interpretation of verbal signs by means of some other language", and intersemiotic translation is "an interpretation of verbal signs by means of signs of nonverbal sign systems" (Jakobson 2000: 233). ${ }^{3}$

Nicola Dusi explains that when dealing "with translation between literary texts and visual $[\ldots]$ texts, the semiotic systems are almost totally separate on the expressive plane. On the content plane, the gambit of translatability remains open" (2015: 182-183). Therefore, images and words use different sign systems, but it is possible for both to address the same or similar meanings.

${ }^{3}$ Jakobson distinguishes "three ways of interpreting a verbal sign: it may be translated into other signs of the same language, into another language, or into another, nonverbal system of symbols" (2000: 233). Their respective labels are: intralingual translation or rewording, interlingual translation or translation proper, and intersemiotic translation or transmutation (233). 
Nilce Pereira argues that illustrations can be seen as a kind of intersemiotic translation "because as a process, the methodologies employed by illustrators are in the majority of cases the same as those adopted by translators to translate a text" (2008: 105). She stresses the interpretative role of illustrations, which create additional meanings for a verbal text (117). Kay L. O'Halloran and others emphasise that intersemiotic translation is the basis of cultural communication (2016: 225), and consider it resemiotisation because it causes "shifts of meaning across semiotic resources which are fundamentally different in nature" (225). Accordingly, shifts in meaning can be expected when illustrations are added to verbal narratives, and, if illustrations are done knowledgeably, intentionally, and in agreement with the (author of) the verbal text, they can be especially relevant for the understanding of a narrative.

These semantic connections between the verbal and the visual texts become even more obvious in the context of interlingual translation. As Emer O'Sullivan points out, when an interlingual translation involves domestication (an adaptation to the target culture), and when the original images accompany it, the result may be "a confusing conglomeration of inconsistent cultural

214 elements" (2005: 85). The overall semantic structure of a narrative is also modified when new illustrations are provided for the translated text, especially if they are introduced regardless of which scenes are depicted in the original and for what reasons, or in departure of the narrative meanings of the original illustrations. Important narrative and cultural meanings may be omitted if the original illustrations are replaced by new ones.

In the present study, the role of images is examined focusing on the semantic relations of the intersemiotic (word-image) translations when new illustrations are provided in the context of interlingual translation. The meanings of new images are compared with the original images.

\section{ILLUSTRATIONS IN SOURCE TEXTS}

The examples of children's classics translated from English into Croatian and selected for this analysis demonstrate tight and meaningful links between words and images, which makes them multimodal texts. A verbal text depends in its overall significance on original illustrations in at least two ways: with respect to the selection of visually presented scenes and with respect to their ingrained intermediality. 
In Alice's Adventures in Wonderland, meanings which become exposed in the intersemiotic translation include characters' features, the playing-cards motif, intertextuality, hypertextuality, ${ }^{4}$ and visualisation of certain verbal expressions or puns. In Winnie-the-Pooh, it is the depiction of characters and (biographical) background information which defines the elements of the story. In fust So Stories, intermedial details become metafictional elements. The tales include images created and commented by Kipling himself, often used to invite the reader to actively participate in the construction of additional narrative meanings. As a result, the tales are exposed as fictional, which is a typical way of creating metafiction. For instance, in "The Elephant's Child" the reader is asked to paint the image. The suggested colours are green for the banana-tree, and red for the Elephant's Child. In result, narrative meanings are modified, however slightly.

The findings of the analysis are presented in two steps; first the focus is on the trends in adopting or replacing original illustrations, and then on the semantic shifts detected in individual examples of new images in target publications. The former step is based on the detection of regularities in publishing practices, and the latter is based on a comparison of original and new illustrations according to two criteria: (1) the selection of scenes, i.e. whether and how the new selection differs from the original set of images, and (2) narrative meanings, i.e. whether analysed images modify them, or not.

\section{TRENDS AND IMPLICATIONS}

The publication history of Croatian translations and retranslations of the selected titles is reconstructed and presented in Tables 1, 2 and 3.

Table 1 shows there are three Croatian editions of fust So Stories, by three different publishers. The text was translated twice. All editions contain original images.

${ }^{4}$ Genette defines intertextuality as "a relationship of copresence between two texts or among several texts" (1997: 1), which is manifested in the practices of quoting, plagiarism or allusion (2). Intertextuality is one of five types of transtextuality, together with paratext, metatextuality, hypertextuality and architextuality. Genette defines hypertextuality as „any relationship uniting a text B (which I shall call the bypertext) to an earlier text A (I shall, of course, call it the bypotext), upon which it is grafted in a manner that is not that of commentary" (5, emphasis in the original). Hypertext is defined as "any text derived from a previous text" (7), either through transformation or through imitation (7). The term" intertextuality" is often is used in literary studies so that it includes the hypertextuality as Genette defines it here. 
Table 1. Croatian editions of fust So Stories

\begin{tabular}{|l|c|l|l|l|l|c|}
\hline Title & Year & \multicolumn{1}{|c|}{ Translator } & City & Publisher & Illustrator & Rp/eds \\
\hline $\begin{array}{l}\text { Kako je deva stekla grbu i } \\
\text { druge priče }\end{array}$ & 1923 & Velikanović & Zagreb & Kugli & Kipling & - \\
\hline Kako je slon stekao surlu & 1987 & Velikanović & Zagreb & SNL & Kipling & - \\
\hline Priče iz džungle & 2008 & Pečnik Kroflin & Zagreb & Algoritam & Kipling & - \\
\hline
\end{tabular}

Winnie-the-Poob stories (Table 2) appeared four times. There was one retranslation. The interlingual translations were published twice each. Three editions were reprinted once each. Two editions include original illustrations, and two new ones, by Nevenka Macolić. There is no specific trend visible regarding this title. Two interlinguistic translations were combined by two sets of images to produce four combinations.

Table 2. Croatian editions of Winnie-the-Poob

\begin{tabular}{|l|l|l|l|l|l|c|}
\hline Title & Year & Translator & \multicolumn{1}{|c|}{ City } & \multicolumn{1}{|c|}{ Publisher } & Illustrator & Rp/eds \\
\hline Medo Winnie zvani Poob & 1986 & Pervan & Zagreb & Mladost & Shepard & 1991 \\
\hline Medo Winnie zvani Pooh & 1996 & Pervan & Varaždin & Katarina Zrinska & Macolić & - \\
\hline Medo Winnie zvani Pooh & 1998 & Leustek & Varaždin & Katarina Zrinska & Macolić & 2005 \\
\hline Medo Winnie zvani Pooh & 2007 & Leustek & Varaždin & Katarina Zrinska & Shepard & 2012 \\
\hline
\end{tabular}

Alice in Wonderland has had many translations and editions (Table 3). There were eight interlinguistic translations published by twelve different publishers. The edition of 1964 had ten reprints. Others had either one or no new editions. Some publishers combined the same translation with different sets of illustrations. Eight editions included Tenniel's illustrations. ${ }^{5}$ The first Croatian edition was adorned by Margaret Tarrant's pictures, from the source text with her illustrations. ${ }^{6}$ Robert Sabuda's pop-up version and

5 Tenniel's illustrations are available in public domain at $<$ https://medium.com/alices-adventures-in-wonderland/sir-john-tenniel-s-classic-illustrations-of-alice-in-wonderland2c3bbdca3a77>. Accessed on 15 May 2018.

6 Tarrant illustrated a luxury London edition published by Ward Lock \& Co., which first appeared in 1916 (Narančić Kovač 2015b: 201). 
its Croatian equivalent are based on Tenniel's illustrations. Once the book appeared without any images.

Table 3. Croatian editions of Alice's Adventures in Wonderland

\begin{tabular}{|c|c|c|c|c|c|c|}
\hline Title & Year & Translator & City & Publisher & Illustrator & Rp/eds \\
\hline Alica u Zemlji Čudesa & 1944 & Jurkić-Šunjić & Zagreb & Matica hrvatska & M. Tarrant & - \\
\hline Alica u Zemlji Čudesa & 1952 & Jurkić-Šunjić & Zagreb & Mladost & J. Tenniel & - \\
\hline Alica u Zemlji Čudesa & 1959 & Jurkić-Šunjić & Zagreb & Mladost & R. Goldoni & - \\
\hline Alica u Zemlji Čudesa & 1964 & Jurkić-Šunjić & Zagreb & Mladost & T. Gusić & $\begin{array}{l}10 \text { by } \\
1991\end{array}$ \\
\hline Alisa u Zemlji čudesa & 1968 & Kereković & Zagreb & Naprijed & J. Tenniel & - \\
\hline $\begin{array}{l}\text { Aličine pustolovine u } \\
\text { Zemlji Čudesa }\end{array}$ & 1985 & Šoljan & Zagreb & $\mathrm{GZH}$ & J. Tenniel & 1989 \\
\hline Alica u Zemlji čudesa & 1995 & Šoljan & Zagreb & Znanje & J. Tenniel & 2000 \\
\hline Alica u Zemlji čudesa & 1995 & Jurkić-Šunjić & Zagreb & Profil International & N. Macolić & 2001 \\
\hline Alica u Zemlji čudesa & 1999 & Jurkić-Šunjić & Zagreb & Školska knjiga & NONE & - \\
\hline $\begin{array}{l}\text { Alicine pustolovine u } \\
\text { Zemlji čuda }\end{array}$ & 1999 & Luca & Split & Laus & J. Tenniel & - \\
\hline Alisa u Zemlji čudesa & 2001 & Raos & Zagreb & Mozaik knjiga & J. Tenniel & 2004 \\
\hline Alica u Zemlji čudesa & 2002 & Paljetak & Zagreb & Kašmir promet & $\begin{array}{l}\text { A. Petrlik- } \\
\text { Huseinović }\end{array}$ & - \\
\hline Alisa u Zemlji čudesa & 2002 & Kezele & Zagreb & $\begin{array}{l}\text { Zagrebačka } \\
\text { stvarnost }\end{array}$ & N. Bešlić & - \\
\hline $\begin{array}{l}\text { Aličine pustolovine u } \\
\text { Zemlji Cudesa }\end{array}$ & 2004 & Šoljan & Zagreb & Školska knjiga & J. Tenniel & 2012 \\
\hline Alica u Zemlji čudesa & 2005 & Šoljan & Zagreb & Magma & $\begin{array}{l}\text { J. Tenniel/ R. } \\
\text { Sabuda }\end{array}$ & - \\
\hline Alisa u Zemlji čudesa & 2010 & Raos & Zagreb & Znanje & J. Tenniel & 2012 \\
\hline Alice u zemlji čudesa & 2016 & Radaković & Zagreb & Edicije Božičević & A. Marinić & - \\
\hline
\end{tabular}

Finally, from 1959 to 2016 there were six sets of new illustrations provided by Croatian artists: Raul Goldoni, Tomo Gusić, Nevenka Macolić, Andrea Petrlik-Huseinović, Nina Bešlić and Antonija Marinić.

Zagreb Mladost published and republished Alice for over 30 years. Školska knjiga and Znanje published two editions each. There does not seem to be any consistency in the selection of individual illustration sets by 
individual publishers. Yet, some interlingual translations were consistently paired with certain illustrations: all the editions of both Šoljan's and Raos's translations use Tenniel's illustrations. In contrast, Jurkić-Šunjićs translation appeared with images by as many as five illustrators, three of them Croatian. This variability can be explained by its repeated appearances in the time span of over 65 years (1944-2001) and by different publishing practices during that time, especially by the publishing house Mladost, responsible for the largest number of reprints.

The translations by Paljetak, Kezele and Radaković come with images by three new illustrators. Tenniel's images adorn the remaining texts.

Overall, the same interlingual translations have been used by different publishers. Tenniel's images have appeared most often. A regularity has been established in fixed combinations of a specific translation and a specific set of illustrations, except for the first and the most enduring translation, which has been combined with several illustration sets.

To establish trends over time, the publishers are divided into three groups, according to the time of their establishment. Kugli and Matica hrvatska stem from the mid-nineteenth century. Their editions in our 218 corpus are interlingual translations published with images from the source texts. These publishers obviously considered illustrations to be an integral part of a text. Besides, they were accustomed to using original images for children's books; it was their decades-long practice to import illustrations (see Majhut and Batinić 2017).?

The second group comprises publishers established after WW2, which dominated the scene during the communist rule, when Croatia was part of former Yugoslavia. Školska knjiga and Znanje still exist, but Naprijed, Mladost, GZH and SNL were closed in the 1990s, when Croatia became an independent state and the democratic system was introduced. Hundreds of new publishers appeared at that time, and many failed. Laus, Magma

${ }^{7}$ In a chapter on the history of Croatian illustrated books, Berislav Majhut and Štefka Batinić explain: "The majority of illustrations of Croatian children's books, especially in the beginning, were by foreign illustrators. Foreign works were translated, and their illustrations were also adopted, or foreign illustrations would be bought, and Croatian texts would be written after them" (2017: 130, translation mine). There were rare cases of new illustrations for a translated text, for instance the images by Vaclav Anderle for the 1888 Kugli's publication of the Croatian translation of Srdce [The Heart] by the Italian author Edmondo de Amicis; Anderle was a Czech living in Croatia at the time (130). There were some domestic illustrators, too. At the turn of the twentieth century there were several Croatian illustrators who provided images for children's books written in Croatian, and there have been ever more such publications since (148ff). 
and Algoritam are now closed, while Profil International, Mozaik knjiga, Katarina Zrinska, Zagrebačka stvarnost, Kašmir promet, and Edicije Božičević are still doing well. ${ }^{8}$

Of the eleven editions issued by the second group of publishers, nine adopt original illustrations, continuing the practice of the first group. Mladost is the only publisher which employed Croatian illustrators, but they also republished Gusić's very sketchy and unattractive illustrations in ten reprints, covering the period of almost 30 years. ${ }^{9}$ Vera Barić, who was the editor of over 80 children's titles during the last decade of the existence of the publishing series Vjeverica [Squirrel] by Mladost (1957-1994), testified that during the second half of the twentieth century, illustrators were selected by the official art editor of the series, based on the "theme and the style of the manuscript" (2016: 147). She also pointed out that children's literature editors in Mladost engaged many successful Croatian artists of the time (147). Therefore, one of the reasons for introducing new illustrations (also in publications of translated literature), was an intention to promote Croatian artists and offer them an additional means of income. Moreover, employing new illustrators could have been less expensive than paying the copyright, and, besides, international connections of publishers in the former Yugoslavia were not always easily established and the editors were somewhat isolated in this sense. ${ }^{10}$ Overall, there was little change.

In contrast, practices of the third group of publishers reveal an inclination towards change; there are eleven editions in our corpus by these publishers, and six of those use illustrations by Croatian artists. Five use the originals, but four of those editions include retranslations. It can be

${ }^{8}$ Matica hrvatska was established in 1842 . The publishing house which belonged to Stjepan Kugli from 1902, was established in 1853; it was closed at the end of WW2. The other publishers were established (and some of them closed) in these years: Naprijed (1945 as Kultura, from 1958 to 2000 as Naprijed), Mladost (1947 as Novo pokoljenje, from 1951 to 1998 as Mladost), GZH - Grafički zavod Hrvatske (1949-1993), Śkolska knjiga (1950), Znanje (1963), SNL - Sveučilišna naklada Liber (1972-1991), Profil international (1991), Mozaik knjiga (1991), Laus (1991-2002), Algoritam (1993-2017), Zagrebačka stvarnost (1993), Katarina Zrinska (1994), Magma (2004-2009), Kašmir promet (1998), and Edicije Božičević (1998).

${ }^{9}$ It seems that the quality or relevance of illustrations did not influence their durability over time (reprints).

${ }^{10}$ In addition to that, avoiding coloured images in children's illustrated books was primarily caused by relatively high printing costs and by the belief that children of the school age were less dependent on illustrations than younger children, who read picturebooks (Barić 2016: 142). 
concluded that trends changed in the 1990s. Before that time, there was a strong tendency of using original (or at least already available) illustrations, and in the most recent period, there is a tendency towards providing new illustrations and new translations. This is further confirmed by the analysis of publishing practices regarding retranslations. While there were only three interlingual translations of Alice throughout the twentieth century, ${ }^{11}$ five retranslations appeared in the twenty-first century, by 2016. Croatian editions of Just So Stories and Poob by the third group of publishers confirm that they encouraged retranslations, while the publishers from the second group continued re-printing already available texts, continuing this practice in the most recent period. The reason for this situation can be that Alice in Wonderland and Winnie-the-Poob have been on the lists of recommended reading in Croatian school curricula, which generally sell better than other titles. As the new publishers could not always use already existing translations, issued by others, they turned to retranslations, hoping to stay on the market.

\section{NEW ILLUSTRATIONS AND NEW MEANINGS}

New illustrations found in Croatian editions of Poob and Alice are analysed and compared with original illustrations by Shepard and Tenniel, respectively. These illustrations are considered canonical source texts because of their specific contribution to the overall narrative meanings of the respective works and their wide recognition as such. Two criteria of comparison in the present research are scene selection and changes in the visual interpretations of the verbal text. ${ }^{12}$

POOH - A TOY OR AN ANIMAL?

The Croatian editions of Poob with illustrations by Macolić do not include the map of the Hundred Aker Wood. Because of this omission, the

${ }^{11}$ Although Sergije Luca signed this edition as a translator, the text is just a compilation of previous translations.

${ }^{12}$ An analysis of images in books that have been illustrated by different artists can be found in a study by Agnes-Margrethe Bjorvand focusing on Astrid Lindren's picturebooks; the differences are interpreted with respect to their functions and narrative meanings (2014). Gabriela Sotto Mayor and Sandie Mourão have developed a typology of (images on) title pages in picturebooks and illustrated books based on their narrative functions (2017). 
metafictional connection between the real place and the fictional setting is severed: the map directly refers to the Five Hundred Acre Wood in Ashdown Forest, near the country home where the Milnes used to spend holidays. Apart from that, the selection of illustrated scenes is similar to that in the original, and new images often follow the original depictions. For example, both sets of images include Christopher Robin pulling his teddy bear upstairs, Pooh sitting in front of his home, Piglet blowing off dandelion, Pooh's dream about an elephant (Heffalump) and the scene when Eeyore needs to have his tail pinned on. In contrast, new images omit some of the scenes from the first chapter: there are no images of Pooh climbing a tall tree, or floating holding on a balloon, and there are no bees.

Further differences are found in depictions of characters, rendering a reinterpretation of important narrative meanings. The protagonists drawn by Shepard clearly resemble the real-life Christopher Robin as a child, and his toys, including his teddy bear Winnie-the-Pooh and Piglet, another soft toy (Figure 1).
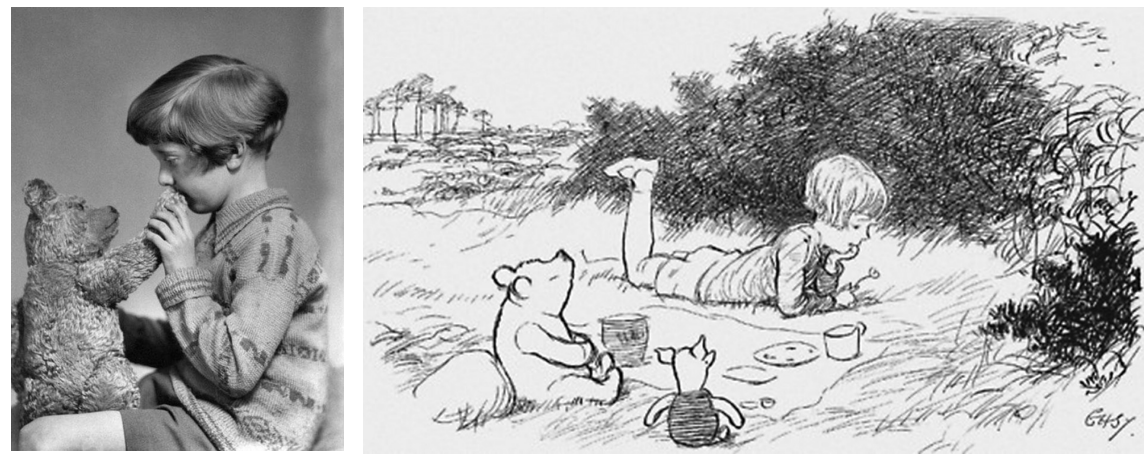

Figure 1. A comparison of the real-life child and toy and of Shepard's visual interpretation of the protagonists. The images are in the public domain.

Macolić changed this: Christopher Robin is not a pre-school child, but somewhat older. She also changed the temporal setting of the tales by dressing up Christopher Robin in a pair of jeans, and giving him a pair of tennis shoes, widely worn by children nowadays (Figure 2). Thus, she severed the link with the authentic biographical context of the source text, but simultaneously established the contemporality of the storyworld and the reader's time, a context similar to that of a reader of the source text in the 1920s. 
More important, the toys appear as anthropomorphised animals, wearing clothes. While Shepard depicts toys in positions which would be possible for them, for example, his Pooh always has straight front paws, Macolić draws them as flexible living creatures. Her Pooh, in a full outfit, sits down with his legs folded and his head resting on his front paws bent at the elbows, like human arms. This modification changes the nature of the narrative turning it into an animal fantasy and shifting its significance away from an imaginary play with toys of the original stories. ${ }^{13}$ This semantic shift is especially problematic when Eeyore loses his tail, and Christopher Robin nails it back onto his toy. Shepard shows Christopher Robin at work, but Macolić is compelled to change this detail, and depicts instead the scene which appears at the beginning of this episode, when Pooh and Eeyore discover that the donkey's tail is missing.

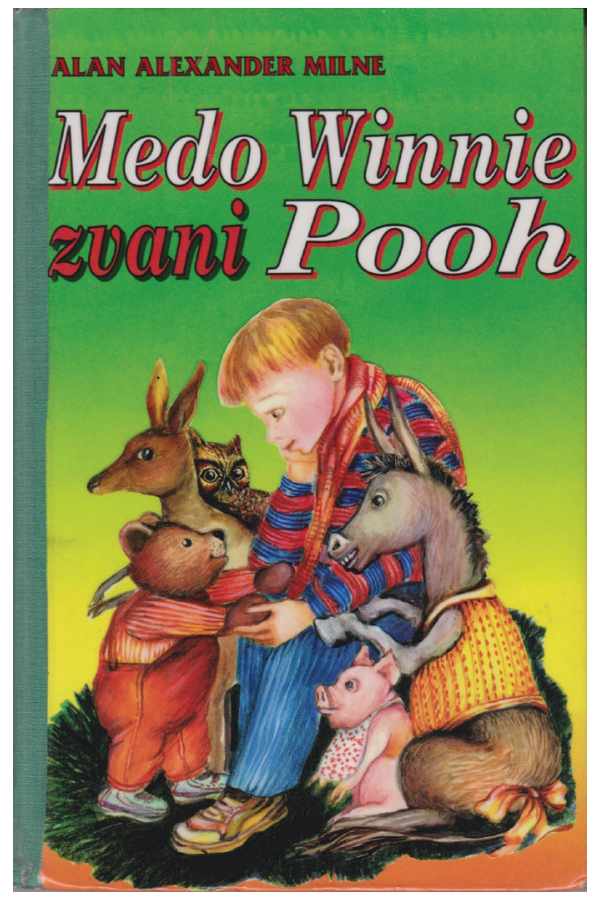

Figure 2. The front cover of the Croatian edition of Winnie-the-Pooh, illustrated by Nevenka Macolić (1998)

13 The original set of characters includes two animals, the Owl and the Rabbit, but they do not wear any clothes and have similar roles as toys. 
It can be concluded that Macolic generally followed the ideas found in the original set of images, which is seen in her selection of scenes and in the composition of several images, which resemble those by Shepard, but she also introduced significant semantic shifts changing the temporal setting of the story and presenting toys as animals, which resulted in a reinterpretation of the narrative.

New images reinterpreted the meaning of the imaginative play. The classical illustrations in the source text follow the primary world of the narrative and depict the toys in a realistic way, in contrast with the verbal meanings of imaginary stories about their adventures. The settings depicted in original pictures do represent spaces of the characters' living places as human-like homes, but the characters themselves, based on real Christopher Robin's toys, remain toys. In the original illustrations, both the boy and the toy characters are presented faithfully to their real models, and the imaginative plots are predominantly created in words rather than in pictures. The new illustrations give preference to the fantasy world. The characters are additionally fictionalised in new illustrations. They do not only talk and move around, but also look like anthropomorphised animals, wearing clothes. In the framing story they are only toys representing animals, just as in the real world of Milne's biography. The fact that this change causes tricky situations (a tail that is pinned onto Eeyore), is simply ignored, and the problem is avoided by skipping the scene. On the other hand, one of Macolić's "prologue pictures" as a paratextual element (see Bjorvand 2014) ${ }^{14}$ represents a boy carrying his teddy bear, definitely a toy, upstairs. It is a hypertext clearly connected with one of the original images by Shepard as its hypotext. Christopher Robin (together with his teddy) is here the boy from the framing story, who has a conversation with the narrator about his toy. This detail further confirms our interpretation of new illustrations. Showing the teddy bear at first as a toy, and then as an animal, marks the

${ }^{14}$ Agnes-Margrethe Bjorland distinguishes between prologue and epilogue pictures and defines them as "usually vignette-like pictures that appear, respectively, at the book's beginning and at its end" (2014: 213). Following Genette, she also claims that these pictures are paratexts (peritexts, more precisely), and that they affect the narrative in different ways (213). Bjorland here refers primarily to picturebooks, but the concepts can also be applied to illustrated books. According to Genette, the term paratext refers to items that a text is related to, but that do not belong to the text itself; it comprises "a title, a subtitle, intertitles; prefaces, postfaces, notices, forewords, etc.; marginal, infrapaginal, terminal notes; epigraphs; illustrations; blurbs, book covers, dust jackets, and many other kinds of secondary signals, whether allographic or autographic" (1987: 3). 
transition from a realistic framing story to the fantastic embedded stories. Regarding the character of Christopher Robin, it is possible that Macolic did not fully recognise the connection of the protagonist with the real child and the relevance of his age for the narrative meanings, or that she simply did not consider this relevant.

This example also shows that paratextual elements, especially prologue pictures, may have a significant function in determining certain narrative meanings in illustrated children's books although paratextual elements in picturebooks generally differ from similar elements in other books according to the "sheer volume of peritexts as well as their form and function" (Bjorland 2014: 215).

The changes found in new illustrations could be considered in terms of metatextuality (see Genette 1997 [1982]: 4), ${ }^{15}$ especially in re-picturing the scenes which were visually presented in the original, but it is more likely that the illustrator just offered her visual interpretation of the stories using the canonical images as hypotexts, than that there was an intention of a commentary on the original images.

\section{APPEARANCES OF ALICE}

It is probable that Matica hrvatska invested ample funds into obtaining Tarrant's illustrations for the first Croatian edition, but those images have never been used in Croatia again. Tenniel's illustrations replaced them in the second Croatian edition of 1952. Afterwards, there were six new sets of images.

The findings of the analysis of the selection of scenes in relevant Croatian editions of Alice are summarised in Table 4. The original Alice (Carroll 1865) contains 42 images. A Croatian edition superseded that number by one, and in other editions the quantity is reduced in comparison with Tenniel's set. All editions generally followed Tenniel in the selection of scenes, so that it is highly probable that new illustrators were acquainted with his work. There are several new scenes selected for intersemiotic translation other than those depicted by Tenniel. Goldoni did not add any new scenes to his selection, three illustrators added between 1 and 4

${ }^{15}$ Gérard Genette defines metatextuality as a type of textual transcendence, "the relationship most often labelled 'commentary'. It unites a given text to another, of which it speaks without necessarily citing it (without summoning it), in fact sometimes even without naming it" (1997: 4). 
scenes, and two added quite a few. A few scenes are shared by two or more illustrators: two portray the Cheshire Cat on the title page, three present Alice falling down the hole, and three focus on the key on the little table, not the bottle, as Tenniel does. Macolić and Petrlik provided several images (24 and 13, respectively) depicting scenes covered exclusively by them, i.e. unique in our corpus.

Table 4. The results of the analyses of new illustrations for Croatian editions of Alice in Wonderland

\begin{tabular}{|l|l|c|c|c|c|}
\hline Year & \multicolumn{1}{|c|}{ Illustrators } & $\begin{array}{c}\text { No of } \\
\text { images }\end{array}$ & JT scenes & New scenes & $\begin{array}{c}\text { Semantic shifts detected } \\
\text { in illustrations }\end{array}$ \\
\hline 1958 & John Tenniel & 42 & & & 3 \\
\hline 1964 & Tomo Goldoni & 9 & 9 & none & 2 \\
\hline 1995 & Nevenka Macolić & 9 & 7 & 2 & 5 \\
\hline 2002 & Andrea Petrlik Huseinović & 23 & 7 & $16(13$ unique $)$ & 4 \\
\hline 2002 & Nina Bešlić & 19 & 15 & 4 & 5 \\
\hline 2016 & Antonija Marinić & 21 & 20 & 1 & 2 \\
\hline
\end{tabular}

Translating Alice into any language is challenging because of its literary, metafictional and stylistic features, and it always demands special engagement and many decisions on the side of the translator. Semantic shifts necessarily appear in interlinguistic translations of this book. Original semantic connections are severed due to the hypertextuality, nonsense, logical jokes, puns and wordplay, intermediality, references to the historical and cultural context, as well as to the author's private sphere and real people, etc.

Regarding intermediality, one of the most difficult spots in this respect is the visual-verbal representation of the Mouse's long tale/tail. ${ }^{16}$ Carroll transferred the verbal pun into a visual representation of a tale/tale and created an intermedial pun impossible to preserve in interlinguistic translations (Narančić Kovač 2016: 309-311). The solution by Raos, who

${ }^{16}$ Salisbury and Styles refer to Lewis Carroll's tail-shaped presentation of "The Mouse's Tale" as an example of the "blurring of boundaries between text as the representation of something visual and text as pictorial element in itself" (2012: 100). 
introduced the shape of the sword and named the tale "The sword of cat's justice," remains a bit awkward in offering such new meanings.

As could be expected, shifts in narrative meanings have been spotted in each set of illustrations by Croatian artists. The appearance of the Cat on the title page, i.e. as a prologue picture, instead of the original frontispiece showing the court room, changes the status of the court trial as the main event of the plot. Before 2016, when the most recent Croatian edition of Alice appeared, none of the Croatian translators or illustrators understood the significance of the nursery rhyme "The Queen of Hearts" for the creation of the literary world of the book, nor did they recognise the centrality of the court scene or the importance of the intentional discrepancy between the verbal references to the identity of the Knave guilty of the theft and the visual reference to the identity of the Knave accused at the trial (see Narančić Kovač and Milković 2011).

Depicting Alice falling down the hole allows for an expansion of the original meanings. Petrlik Huseinović used this opportunity. Her Alice falls down together with a number of animals and objects: two mice and a turtle, a snail in a little house (a visual joke and an intermedial pun as the snail is 226 looking out of the window of a cuboid house with a roof and a chimney on it), a framed silhouette of an ambiguous meaning (showing either a man with a cap or a two-faced creature), a book, a teapot, a cup, a pen, a watch, a key, a gingerbread man, two aces (of spades and of hearts), a bottle, a candy cane, a cube of sugar, and two leaves. This intersemiotic translation reinterprets the narrative. The semantic shift implies that creatures and objects Alice would later encounter in Wonderland came with her from the primary world, while in the original there is no such implication. The presence of small animals implies that Mouse and Mock Turtle are just imaginary transformations of real animals. In the original, Mock Turtle originates from an utterance of natural language: "mock turtle soup," meaning turtle soup which is not genuine, but an imitation. ${ }^{17}$ A "mock turtle" is an impossible being, and exactly the kind of character that belongs to a nonsensical and absurd secondary world typical of Carroll's narratives. His practice of using natural language and its forms and expressions to introduce new characters, settings and events is rarely preserved in interlingual translations. Petrlik Huseinović thus reinterprets some elements of the original literary world, and adds new meanings: the gingerbread man is familiar to most Croatian children, who learn English at school from the first grade, and would be

${ }^{17}$ For a more detailed explanation, see Narančić Kovač 2016: 300. 
recognised as coming from the British culture and tradition. This is a subtle indication of the setting of Alice, non-existent in the original.

Other semantic shifts detected in illustrations by Croatian artists are mostly related to some characters and the plot.

The most obvious shift appears in the depiction of Mock Turtle, which does not have any calf parts in two sets of images (Goldoni, Macolić), and Gusić does not depict him at all. Mock Turtle has the head, the tail and hind legs of a calf because mock turtle soup used to be made from veal. The presentation of the character gradually gets closer to the classic illustrations of the source text only in the twenty-first century. Petrlik Huseinović gives him a different head, but it is hard to tell if it is a roe deer's, a kangaroo's, or a calf's head. Bešlić gives him a tail which could belong to a calf, but looks exactly like that of her Gryphon, so it is rather like a lion's tail. Mock Turtle also has a beak, again like his companion. Marinić's Mock Turtle is modelled after Tenniel's, with all the calf parts in right places. There is a slight semantic shift in the depiction of his eyes - while Tenniel's Turtle has calf eyes, this one's eyes are human. ${ }^{18}$

Macolić added a new character based on the new poem included in the interlingual translation by Jurkić-Šunjić, about "Guska Gagača” 'the Goose Honkhoker'. This indicates that Macolić used the target text, and not the source text to produce her (visual) intersemiotic translation.

Other semantic shifts in this category include: an especially scary and repulsive Cheshire Cat (Gusić), and a confused one (Petrlik Huseinović), a brown White Rabbit blended with the March Hare, the royals without any connection with playing cards, the Crocodile with a toothbrush (Macolić) and Alice as a troubled teenager, with circles under her eyes and a perplexed gaze (Marinić).

Modifications of the plot include a Mad Tea Party without the Dormouse (Goldoni), and another where the Turtle joins in, while it is doubtful if tea or coffee is served (Petrlik Huseinović) ${ }^{19}$. The original Mad Hatter and March Hare wake up Dormouse by pushing it into the teapot, and in Bešlićs reinterpretation they push a cat-like animal into a bowl. At the trial,

\footnotetext{
${ }^{18}$ Radaković’s interlingual translation renders the Mock Turtle as "Teleća Kornjača”, "Calf Turtle".

${ }^{19}$ We can see honey on the table, and a jug (of milk). Drinking tea with honey is typical for the Croatian context. The dark liquid in cups could be either tea or coffee, so perhaps they are having coffee, which is often drank with milk in Croatia. Emer O'Sullivan has spotted similar instances of domestication "in several German versions of Alice in Wonderland, [where] the Mad Hatter serves coffee instead of tea" (2005: 85).
} 
the main piece of evidence, a tray of tarts, is either missing (Goldoni), or there is a large table covered with trays full of cakes and sweets (Gusić). Finally, although the visual presentation of the scene by the pool of tears is made in imitation of Tenniel's image, Dodo is sadly omitted (Bešlić).

Semantic shifts found in Croatian editions of Alice are not many, but they are sometimes significant because they change important narrative meanings. Judging from the selections of scenes for illustration, the artists seem to have been acquainted with Tenniel's original images. However, most of them demonstrated a relatively low level of awareness of complex intermedial connections between the verbal and the visual elements in the original, and of narrative meanings which depend on this sophisticated visual-verbal relationship. The reason for this may be the widely spread opinion, or rather a fallacy, that children's literature is always simple, and that it does not require special effort. Alice belies this belief.

Even when certain scenes are imitated, and narrative meanings are modified, this does not seem to be because of an intention to provide commentary on the canonical illustrations of the source text or to establish a dialogue with the complex source text and its intermediality. Therefore, there is no real metatextuality in either of these sets of images. The creators of new sets of illustrations are more concerned with demonstrating their own artistic style than with narrative meanings (Goldoni, Gusić, Bešlić), or simply focused on their individual intersemiotic translations (and interpretations) of the verbal text (Macolić, Petrlik).

Yet, the set created by Marinić seems to have been done after a careful study and thoughtful consideration of narrative meanings, and probably in cooperation with the interlingual translator. The trial scene in this edition confirms such an evaluation because it successfully transfers the visual riddle from the original into the target text.

\section{CONCLUSION}

Based on the results of the analysis, it can be concluded that the status of illustrations in published translations of children's classics from English into Croatian depends on the publication policies followed by a certain group of publishers. The twentieth-century publishers established after WW2 rarely initiated new interlinguistic translations (retranslations) or intersemiotic translations and preferred the original illustrations in their 
editions (except for the publisher Mladost). The trend slightly changed with the appearance of new publishers in the 1990s, who show a tendency towards introducing and publishing retranslations and new intersemiotic translations. However, although different combinations of interlingual and intersemiotic translations do exist, most pairs of Croatian texts and sets of images remain constant.

Croatian illustrators follow the originals in the selection of scenes. While they often imitate the original illustrations, they never adopt the whole selection. They tend to provide new images, which sometimes modify original narrative meanings, introduce semantic shifts and offer reinterpretations. Regarding hypertextuality, both Shepard's and Tenniel's original illustrations remain detectable as hypotexts of newly made illustration sets. For those who are familiar with the canonical illustrations, they present a cultural background that the new sets are necessarily seen against, and thus exposed to implicit evaluation by comparison with the originals.

New illustrations and retranslations may betray some original meanings, but they also verify the vitality of children's literature classics, which find a new life in another culture by means of new interlingual and intersemiotic translations, including intriguing semantic shifts.

\section{WORKS CITED}

Barić, Vera. 2016. "Vera Barić - tisuće stranica za djecu." Interviewed by Vesna Radošević. Libri \& Liberi 5, 1: 137-150.

Bjorvand, Agnes-Margrethe. 2014. "Prologue and Epilogue Pictures in Astrid Lindgren's Picturebooks.” In: Picturebooks: Representation and Narration. Ed. Bettina Kümmerling-Meibauer. New York and London: Routledge: 213-226.

Dusi, Nicola. 2015. "Intersemiotic Translation: Theories, Problems, Analysis." In: Semiotica 206: 181-205.

Genette, Gérard. 1997 (1982). Palimpsests: Literature in the Second Degree. Trans. Channa Newman and Claude Doubinsky. Lincoln and London: University of Nebrasca Press.

Jakobson, Roman. 2000 (1959). "On Linguistic Aspects of Translation." In: The Translation Studies Reader. Ed. Lawrence Venuti. London and New York: Routledge: 113-118.

Kümmerling-Meibauer, Bettina. 2010. "Remembering the Past in Words and Pictures: How Autobiographical Stories Become Picturebooks." In: New Directions in Picturebook Research. Eds. Teresa Colomer, Bettina Kümmerling-Meibauer and Cecilia Silva-Díaz. New York: Routledge: 205-216.

Lewis, David. 2001. Reading Contemporary Picturebooks: Picturing Text. London and New York: Routledge/Falmer. 
S. Narančić Kovač, The Status of Illustrations in Croatian Translations of Children's Classics (211-230)

"Umjetnost riječi" LXIII (2019) • 3-4・Zagreb • July - December

Majhut, Berislav and Štefka Batinić. 2017. Hrvatska slikovnica do 1945. Zagreb: Hrvatski školski muzej and Učiteljski fakultet Sveučilišta u Zagrebu.

Narančić Kovač, Smiljana. 2015a. Fedna priča - dva pripovjedača: slikovnica kao pripovijed. Zagreb: ArTresor.

Narančić Kovač, Smiljana. 2015b. "Alica speaks Croatian." In: Alice in a World of Wonderlands: The Translations of Lewis Carroll's Masterpieces. Volume One: Essays. Ed. Jon A. Lindseth. New Castle, DE: Oak Knoll Press: 201-206.

Narančić Kovač, Smiljana. 2016. "Translating Intertext and Intermedial Meanings: Problems with Alice." In: Translation and Meaning. New Series. Vol 2, Pt 1. Eds. Barbara Lewandowska-Tomaszczyk, Łukasz Bogucki and Marcel Thelen. Frankfurt/Main and New York: Peter Lang: 289-318.

Narančić Kovač, Smiljana and Ivana Milković. 2011. "Tko je ukrao kolačiće: intertekstualna sastavnica Aličinih pustolovina u Čudozemskoj u hrvatskim izdanjima." In Redefiniranje tradicije. Eds. Ante Bežen and Berislav Majhut. Zagreb: Učiteljski fakultet and ECNSI: 223-240.

Nikolajeva, Maria, and Carole Scott. 2001. How Picturebooks Work. New York: Garland Publishing.

O'Halloran, Kay L., Sabine Tan and Peter Wignell. 2016. "Intersemiotic Translation as Resemiotisation: A Multimodal Perspective.” Signata 7: 199-229.

O'Sullivan, Emer. 2005. Comparative Children's Literature. London and New York: Routledge.

230 Pereira, Nilce M. 2008. "Book Illustration as (Intersemiotic) Translation: Pictures Translating Words." Meta 53, 1: 104-119.

Salisbury, Martin and Morag Styles. 2012. Children's Picturebooks: The Art of Visual Storytelling. London: Laurence King Publishing.

Shavit, Zohar. 1986. Poetics of Children's Literature. Athens: The University of Georgia Press.

Sotto Mayor, Gabriela and Sandie Mourão. 2017. "A Typology of Title Pages: A Comparative Analysis between Portugal and the United Kingdom.” In: 5th International Conference on Illustration and Animation. Book of Proceedings. Ed. Paula Tavares and Pedro Mota Teixeira. Barcelos: Instituto Politécnico do Càvado e do Ave: 622-631.

Whalley, Joyce Irene. 2004. "The Development of Illustrated Texts and Picture Books." In: International Companion Encyclopedia of Children's Literature. Ed. Peter Hunt. London: Routledge: 318-327. 